\title{
FAKTOR PENYEBAB KETERLAMBATAN WAKTU PENGEMBALIAN BERKAS REKAM MEDIS RAWAT INAP DI RS ESTOMIHI MEDAN TAHUN 2019
}

\author{
Erlindai \\ Dosen Prodi D-III Perekam Dan Infokes Imelda, Jalan Bilal Nomor 52 Medan
}

E-mail: erlindaipurba@gmail.com

\begin{abstract}
ABSTRAK
Aspek ketepatan waktu pengembalian berkas rekam medis rawat inap harus sesuai dengan SPO yang ditetapkan oleh rumah sakit Estomihi yaitu $2 \times 24$ jam setelah pasien pulang dan sudah dalam keadaan lengkap. Oleh karena itu perlu adanya evaluasi faktor penyebab keterlambatan waktu pengembalian berkas rekam medis rawat inap untuk meningkatkan mutu pelayanan rumah sakit. Penelitian ini bertujuan untuk mengetahui penyebab ketidaktepatan waktu pengembalian berkas rekam medis rawat inap, jenis penelitian ini yaitu deskriptif, teknik pengumpulan data menggunakan observasi, kuisioner dan wawancara. Dari hasil penelitian yang dilakukan diketahui bahwa jumlah ketidaktepatan waktu pengembalian berkas rekam medis sebesar 63 atau $72,41 \%$ berkas rekam medis rawat inap dan jumlah berkas yang tepat waktu sebesar 24 atau 27,59\%. Faktor penyebab keterlambatan waktu pengembalian berkas rekam medis rawat inap yaitu disebabkan oleh dokter yang terlambat mengisi kelengkapan berkas rekam medis, belum adanya petugas khusus pengembalian berkas rekam medis rawat inap, serta jarak Instalasi rawat inap ke Instalasi rekam medis yang cukup jauh sehingga mengakibatkan keterlambatan pengembalian berkas rekam medis rawat inap ke Instalasi rekam medis. Saran sebaiknya pihak rumah sakit melakukan sosialisasi dan mengingatkan kembali dokter dan profesi medis yang lain saat rapat tentang ketepatan pengembalian berkas rekam medis agar lebih disiplin dalam melengkapi berkas rekam medis sesuai dengan kebijakan SPO sehingga pengembalian berkas rekam medis tidak mengalami keterlambatan.
\end{abstract}

Kata Kunci: Pengembalian Berkas, Rekam Medis Rawat Inap.

\begin{abstract}
The timeliness aspect of returning the inpatient medical record file must be in accordance with the SPO determined by the Estomihi hospital, which is $2 \times 24$ hours after the patient has returned and is in complete condition. Therefore it is necessary to evaluate the factors causing the delay in returning the inpatient medical record file to improve the quality of hospital services. This study aims to determine the cause of inaccurate return of inpatient medical record files, this type of research is descriptive, data collection techniques using observation, questionnaires and interviews. From the results of the research conducted, it is known that the number of inaccuracies in returning the medical record file is 63 or $72.41 \%$, the inpatient medical record file and the number of timely files is 24 or $27.59 \%$. Factors causing delays in returning the inpatient medical record file are caused by doctors who are late filling in the completeness of medical record files, the absence of special officers returning inpatient medical record files, as well as the distance of inpatient installations to medical record installations that are far enough to cause delay in returning record files medical hospitalization to medical record installation. Suggestions should the hospital do socialization and remind doctors and other medical professions during the meeting about the accuracy of returning medical record files to be more disciplined in completing the medical record file in accordance with the SPO policy so that the return of the medical record file is not delayed.
\end{abstract}

Keywords: File Returns, Inpatient Medical Records. 


\section{PENDAHULUAN}

Berdasarkan (Undang-undang Nomor 44, 2009) tentang rumah sakit, bahwa rumah sakit yaitu institusi pelayanan kesehatan yang menyelenggarakan pelayanan kesehatan perorangan secara paripurna dan menyediakan pelayanan rawat inap, rawat jalan dan gawat darurat. Fungsi rumah sakit yaitu penyelenggaraan pelayanan pengobatan dan pemulihan kesehatan sesuai dengan standar pelayanan yang ada di rumah sakit. Salah satu peningkatan mutu pelayanan disarana kesehatan yaitu peningkatan mutu di unit rekam medis.

Berdasarkan (PERMENKES RI Nomor 71, 2013), disebutkan bahwa rawat inap adalah pelayanan kesehatan perorangan yang bersifat non spesialistik dan dilaksanakan pada fasilitas kesehatan tingkat pertama untuk keperluan observasi, perawatan, diagnosis, pengobatan dan pelayanan medis lainnya dimana pasien dirawat di instalasi rawat inap paling singkat 1 hari.

Menurut PERMENKES RI Nomor 269/MENKES/Per/III/2008, disebutkan bahwa rekam medis merupakan berkas yang berisi catatan dan dokumen tentang identitas pasien, pemeriksaan, pengobatan, tindakan dan pelayanan lain yang telah diberikan kepada pasien ataupun yang diterima pasien. Untuk mendapatkan kinerja instalasi rekam medis yang berkualitas maka dalam proses penyelenggaraan rekam medis harus dilakukan dengan benar dan tepat. Termasuk dalam pengembalian rekam medis. Setelah pasien pulang berkas rekam medis pasien harus dilengkapi/diisi terlebih dahulu oleh perawat dan dokter, setelah itu berkas rekam medis pasien dapat dikembalikan dari ruang perawatan kebagian rekam medis.

Mengingat pentingnya kegunaan rekam medis dan dampak keterlambatan waktu pengembalian berkas rekam medis maka akan mempersulit pelaksanaan petugas bagian assembling. Oleh karena itu berkas rekam medis pasien harus segera di kembalikan ke Instalasi rekam medis paling lambat 2x24 jam setelah pasien pulang secara lengkap dan benar (Depkes RI, 2006).
Berdasarkan penelitian (Renantha, 2017) yang dilakukan di RSPAU dr. Suhardi Hardjolukito Yogyakarta mengenai ketepatan waktu pengembalian berkas rekam medis rawat inap, menunjukkan bahwa seluruh berkas rekam medis rawat inap yang dikembalikan ke bagian assembling selama bulan Juli 2017 dari 10 bangsal yaitu sebanyak 272 berkas rekam medis. Pengembalian berkas rekam medis yang tidak tepat waktu sebanyak 145 atau 53,30\% sedangkan pengembalian berkas rekam medis yang tepat waktu sebanyak 127 berkas atau 46,70\%. Faktor-faktor yang menyebabkan terjadinya keterlambatan waktu pengembalian berkas rekam medis rawat inap yaitu disebabkan karena kurangnya petugas rekam medis yang sesuai dengan bidang keilmuannya, kepatuhan, ketelitian dan pemahaman pertanggungjawaban dalam pengembalian berkas rekam medis rawat inap. Serta sosialisasi yang sudah pernah dilakukan tetapi belum dilaksakan secara maksimal.

Berdasarkan pengamatan yang dilakukan di RS Estomihi Medan, yang penulis dapatkan yaitu untuk mengetahui apakah dokumen rekam medis terlambat atau tidak terlambat bisa dilihat dari buku ekspedisi yang ada di ruangan assembling. Keadaan yang ada di rumah sakit tersebut yaitu dimana masih sering terjadinya keterlambatan waktu pengembalian berkas rekam medis yang berhari-hari atau lebih dari $2 \times 24$ jam setelah pasien pulang. Ratarata jumlah seluruh berkas rekam medis rawat inap yang dikembalikan ke bagian assembling perbulannya dari 4 bangsal diperkirakan sebanyak 250 berkas rekam medis. Pengembalian berkas rekam medis yang tidak tepat waktu diperkirakan sebanyak 199 berkas atau 79,6\% sedangkan pengembalian berkas rekam medis yang tepat waktu sekitar 51 berkas atau 20,4\%.

Penyebab dalam keterlambatan pengembalian berkas rekam medis pasien rawat inap yaitu tingkat kedisiplinan dokter dalam tanggung jawab pengisian data pada berkas rekam medis terutama pada bagian resume medis masih kurang tertib, tidak adanya petugas khusus pengembalian berkas rekam medis dan jarak antara Instalasi rawat 
inap ke Instalasi rekam medis cukup jauh. Sehingga banyak rekam medis pasien yang masih berada di ruang perawatan hingga berhari-hari. Oleh karena itu penelitian ini dilakukan untuk mengetahui lebih lanjut faktor penyebab keterlambatan pengembalian berkas rekam medis di RS Estomihi Medan.

Berdasarkan permasalahan di atas penulis tertarik untuk melakukan penelitian dengan judul "Faktor Penyebab Keterlambatan Waktu Pengembalian Berkas Rekam Medis Rawat Inap Di RS Estomihi Medan".

\section{METODE PENELITIAN}

Jenis penelitian ini menggunakan penelitian deskriptif. Penelitian deskriptif yaitu penelitian yang dilakukan terhadap sekumpulan objek yang biasanya bertujuan untuk melihat gambaran yang terjadi didalam suatu populasi tertentu. (Notoatmodjo, 2012). Metode yang digunakan adalah observasi, kuesioner dan wawancara. Waktu penelitian ini dilaksanakan pada Bulan Februari-April 2019. Tempat yang dipilih peneliti ialah RS Estomihi di jl. Sisingamangaraja No. 235, Sudirejo II, Medan Kota di karenakan RS Estomihi Medan.

Populasi merupakan keseluruhan sumber data yang diperlukan dalam suatu penelitian (Saryono dkk, 2013). Populasi dalam penelitian ini adalah seluruh berkas rekam medis rawat inap pada Bulan
Februari-April 2019 di Rs Estomihi Medan sebanyak 693 dan petugas rekam medis 3 orang. Sampel adalah objek yang diteliti dan dianggap mewakili seluruh populasi. (Notoatmodjo, 2012) besar sampel dalam penelitian ini dengan menggunakan Rumus Slovin yaitu :

$$
\begin{aligned}
& n= \frac{N}{1+N(d)^{2}} \\
& \text { Keterangan: } \\
& \mathrm{n}=\text { Jumlah sampel } \\
& \mathrm{N}=\text { Jumlah Populasi } \\
& \mathrm{d}^{2}=\text { Tingkat ketepatan Absolute }(0.1) \\
& \text { maka didapatkan : } \\
& \mathrm{n}=\frac{693}{1+693(0,1)^{2}} \\
& \mathrm{n}=\frac{693}{1+693(0.01)} \\
& \mathrm{n}=\frac{693}{7,93} \\
& \mathrm{n}=87 \text { berkas rekam medis }
\end{aligned}
$$

Teknik sampling dalam penelitian ini menggunakan teknik random sampling, yaitu cara pengambilan sampel dari semua anggota populasi yang dilakukan secara acak tanpa memperhatikan nama, pendidikan, penyakit, ataupun umur yang ada dalam anggota populasi. Menurut (Notoatmodjo, 2012) Random Sampling yang mana teknik pengambilan sampel secara acak. Teknik random sampling ini hanya boleh digunakan apabila setiap unit atau anggota populasi itu bersifat homogen. Jadi setiap anggota populasi itu mempunyai kesempatan yang sama untuk diambil sebagai sampel.

\section{Definisi operasional}

Tabel 1. Definisi Operasional

\begin{tabular}{llll}
\hline No & \multicolumn{1}{c}{ Variabel } & \multicolumn{1}{c}{ Definisi Operasional } & Alat Ukur \\
\hline 1 & Ketidaklengkapan & Ketidaklengkapan adalah adanya kekurangan Lembar checklist \\
& pengisian berkas rekam & dalam pengisian berkas rekam medis yang & observasi \\
& medis & seharusnya diisi oleh perawat dan dokter yang & \\
& & merawat pasien dan membubuhkan tanda tangan & \\
& & serta nama jelas yang harus dilengkapi & \\
& selambat-lambatnya 2x24 jam setelah pasien & \\
\hline 2. & Petugas pengembalian & Petugas rekam medis yang pengetahuannya Kuesioner \\
& berkas rekam medis yang & sesuai dengan bidang keilmuannya sangat & \\
& pengetahuannya sesuai & bertanggung jawab dalam pengembalian berkas & \\
dengan bidang & rekam medis sehingga pengembalian dapat & \\
keilmuannya & berjalan lebih cepat untuk mengurangi & \\
& ketidaktepatan waktu pengembalian berkas & \\
&
\end{tabular}


rekam medis rawat inap.

\begin{tabular}{|c|c|c|c|}
\hline 3 & Jarak pengembalian & $\begin{array}{l}\text { Jarak adalah angka yang menunjukkan seberapa } \\
\text { jauh suatu berkas berubah posisi melalui tempat } \\
\text { tertentu. Jarak antara instalasi rawat inap dengan } \\
\text { instalasi berkas rekam medis yang jauh dan } \\
\text { tidak dibantu menggunakan sarana seperti lift } \\
\text { akan memperlambat proses pengembalian } \\
\text { berkas rekam medis. }\end{array}$ & $\begin{array}{ll}\text { Lembar } & \text { checklist } \\
\text { observasi } & \end{array}$ \\
\hline 4 & $\begin{array}{l}\text { Keterlambatan } \\
\text { pengembalian berkas } \\
\text { rekam medis }\end{array}$ & $\begin{array}{l}\text { pengembalian berkas rekam medis dari unit } \\
\text { rawat inap ke unit rekam medis apabila melebihi } \\
\text { batas waktu pengembalian yaitu maksimal } 2 \times 24 \\
\text { jam setelah pasien pulang. }\end{array}$ & $\begin{array}{l}\text { Wawancara } \\
\text { mendalam }\end{array}$ \\
\hline
\end{tabular}

\section{Analisa Data}

Analisis data yang dilakukan dalam penelitian ini dengan cara deskriptif. Dalam penelitian ini untuk menunjang penyajian data agar mudah dimengerti, maka menggunakan tabel presentase. Berikut frekuensi relatif:

$P=\frac{F}{N} \times 100 \%$

$\mathrm{f}=$ frekuensi yang sedang dicari

$\mathrm{N}=$ Number of Cases (banyaknya individu)

$\mathrm{P}=$ angka presentase

Rumus Pendekatan Skala Gutman

Rumus Umum

Interval $(\mathrm{I})=$ Range $(\mathrm{R}) /$ Kategori $(\mathrm{K})$

Range $(\mathrm{R})=$ skor tertinggi - skor terendah

$$
=100-0=100 \%
$$

Kategori $(\mathrm{K})=3$ adalah banyaknya kriteria yang disusun pada kriteria objektif suatu variabel

Kategori yaitu: Baik, Cukup dan Kurang

Interval $(\mathrm{I})=100 / 3=33,33 \%$

Kategori Persentase

Baik :76\%-100\%

Cukup : $56 \%-75 \%$

Kurang : $0-55 \%$

\section{HASIL PENELITIAN}

\section{Pengembalian Berkas Rekam Medis}

Setelah dilakukan penelitian dan pengumpulan data oleh peneliti mengenai "Faktor Penyebab Keterlambatan Waktu Pengembalian Berkas Rekam Medis Rawat Inap Di Rumah Sakit Estomihi Medan" maka diperoleh keterangan bahwa berkas rekam medis rawat inap dari instalasi rawat inap harus sudah dikembalikan ke instalasi rekam medis dalam waktu $2 \times 24$ jam setelah pasien pulang.

Pengembalian berkas rekam medis rawat inap dari instalasi rawat inap ke instalasi rekam medis di RS Estomihi dalam kurun waktu 2x24 jam masih terjadi keterlambatan. Berdasarkan dari wawancara yang dilakukan pada tanggal 7 Maret 2019 kepada responden 1 mengenai apakah masih sering terjadi keterlambatan dalam pengembalian berkas rekam medis rawat inap.

Responden 1 memberikan keterangan sebagai berikut:

Masih sering terjadi keterlambatan

Responden 1

Masih sering terjadi keterlambatan, bahkan sampai berhari-hari diruangan rawat inap

Responden 2

Masih ada sebagian berkas rekam medis yang terlambat

Responden 3

Berdasarkan hasil penelitian di RS

Estomihi Medan diketahui jumlah seluruh berkas rekam medis rawat inap yang

dikembalikan ke assembling selama Bulan Februari-April 2019 yaitu berkas rekam medis terdiri dari 4 bangsal. Dari 693 berkas 
rekam medis, sampel yang peneliti ambil sebesar 87 berkas rekam medis. Dari 87 berkas rekam medis terdapat yang tidak tepat waktu berjumlah 63 berkas rekam medis dan berkas rekam medis yang tepat waktu berjumlah 24 berkas rekam medis.

Tabel 2. Pengembalian Berkas Rekam Medis Rawat Inap

\begin{tabular}{ccccccc}
\hline No & Bangsal & Jumlah Berkas & Tepat Waktu & \% & Tidak tepat waktu & \% \\
\hline 1 & Maria & 20 & 9 & $45 \%$ & 11 & $55 \%$ \\
\hline 2 & Martha & 18 & 3 & $16,67 \%$ & 15 & $83,33 \%$ \\
\hline 3 & Naomi & 27 & 6 & $22,22 \%$ & 21 & $77,78 \%$ \\
\hline 4 & Ribka & 22 & 6 & $27,27 \%$ & 16 & $72,73 \%$ \\
\hline & Jumlah & 87 & 24 & $27,59 \%$ & 63 & $72,41 \%$
\end{tabular}

Dari tabel diatas menunjukkan bahwa keterlambatan pengembalian berkas rekam medis rawat inap dari instalasi rawat inap ke instalasi rekam medis pada Bulan Februari April 2019 paling banyak pada bangsal Naomi sebanyak 21 atau $77,78 \%$ berkas tidak tepat waktu dari 27 berkas rekam medis dan keterlambatan paling sedikit pada

bangsal Maria sebanyak 11 atau 55\% dari 20 berkas rekam medis.

Total presentase ketidaktepatan waktu pengembalian berkas rekam medis sebagai berikut:

$\frac{\text { Jumlah berkas rekam medis tidak tepat waktu }}{\text { jumlah seluruh berkas rekam medis }} \times 100 \%$ $=\frac{63}{87} \times 100 \%$

$=72,41 \%$

\section{Faktor Penyebab Keterlambatan Waktu Pengembalian Berkas Rekam Medis Rawat Inap} Disebabkan Oleh 3 Faktor Yaitu:

1. Tingkat kedisplinan dokter dan tanggung jawab dokter dalam pengisian data pada berkas rekam medis terutama pada bagian resume medis

Berdasarkan hasil wawancara dengan responden 1 atau kepala rekam medis yang dilakukan tanggal 7 Maret 2019 di Instalasi Rekam Medis didapatkan keterangan sebagai berikut:

Dokter nya malas dalam melengkapi berkas rekam medis jika total berkas rekam medis nya hanya ada 3 ataupun 4 . Oleh sebab itu setelah berkas bertumpuk di ruangan maka dokter akan melengkapi berkas rekam medis. Dokter selalu diingatkan oleh perawat untuk melengkapi berkas rekam medis, tetapi dokter selalu menunda hingga berkas rekam medis menumpuk diruangan. berkas yang tidak lengkap lebih sering di bagian resume medis dan tanda tangan dokter.

Responden 1 2019

Berikut keterangan responden 2 yaitu petugas assembling yang dilakukan tanggal 7 Maret

Keterlambatan pengembalian berkas rekam medis lebih sering disebabkan oleh dokter yang tidak melengkapi berkas rekam medis pasien. Terkadang setelah berkas rekam medis dilengkapi oleh dokter, berkas tidak langsung dikembalikan perawat ke ruang rekam medis dikarenakan beban kerja perawat di ruangan rawat inap.

Responden 2

Keterangan yang sama juga didapatkan dari responden 3 yang dilakukan pada tanggal 7 Maret 2019

Penyebab keterlambatan pengembalian berkas rekam medis disebabkan oleh dokter dan perawat yang tidak melengkapi berkas rekam medis rawat inap. Dan terkadang dokter membawa berkas rekam medis pulang kerumah untuk dilengkapi, setelah selesai dilengkapi dokter maka berkas rekam medis dikembalikan ke rumah sakit.

Responden 3

2. Petugas Pengembalian Berkas Rekam Medis Yang Pengetahuannya Sesuai Dengan Bidang Keilmuan Nya
Berdasarkan observasi yang dilakukan belum adanya petugas khusus dalam pengembalian berkas rekam medis rawat 
inap. Petugas yang bertanggung jawab dalam pengembalian berkas rekam medis yaitu perawat. Hasil wawancara dengan Yang bertugas dalam pengembalian berkas rekam medis rawat inap ialah perawat.

Responden 1

Biasanya yang mengembalikan berkas rekam medis rawat inap ke instalasi rekam medis dilakukan oleh perawat. Di rumah sakit estomihi belum ada petugas khusus dalam pengembalian berkas rekam medis. Kalau berkas rekam medis belum dikembalikan ke Instalasi rekam medis maka petugas rekam medis mengingatkan perawat dengan cara menelfon keruangan perawat agar berkas rekam medis dikembalikan ke Instalasi rekam medis.

Responden 2

Rumah sakit masih kekurangan SDM bagian rekam medis, tetapi karena faktor keuangan yang belum cukup untuk menggaji pegawai maka belum dilakukan penambahan SDM. Seharusnya ada petugas khusus dalam pengembalian berkas rekam medis rawat inap, tetapi karena belum ada petugas khususnya maka pengembalia berkas rekam medis rawat inap dilakukan oleh perawat di setiap ruangan.

Responden 3

Untuk mengetahui gambaran pengetahuan petugas rekam medis tentang ketepatan waktu pengembalian berkas rekam medis rawat inap di RS Estomihi Medan, digunakan analisis deskriptif berdasarkan tanggapan atas pertanyaan-pertanyaan dalam kuisioner. Item-item pertanyaan dalam pengetahuan petugas rekam medis digambarkan dalam bentuk tabel deskriptif frekuensi.

Tabel 3. Kuesioner Pengetahuan Petugas Rekam Medis

\begin{tabular}{|c|c|c|c|c|c|c|}
\hline \multirow[b]{2}{*}{ No } & \multirow{2}{*}{ Pernyataan } & \multicolumn{2}{|c|}{ Benar } & \multicolumn{2}{|c|}{ Salah } & \multirow[t]{2}{*}{ Kategori } \\
\hline & & $\mathbf{N}$ & $\mathbf{F}(\%)$ & $\mathbf{N}$ & $\mathbf{F}(\%)$ & \\
\hline 1 & $\begin{array}{l}\text { Rekam medis pasien yang pulang atau } \\
\text { meninggal harus dikembalikan } 2 \times 24 \text { jam }\end{array}$ & 3 & 100 & 0 & 0 & Baik \\
\hline 2 & $\begin{array}{l}\text { Catatan perawat harus diisi lengkap sebelum } \\
\text { dikembalikan ke unit kerja rekam medis }\end{array}$ & 3 & 100 & 0 & 0 & Baik \\
\hline 3 & $\begin{array}{l}\text { Pengembalian berkas rekam medis rawat inap } \\
\text { berdasarkan SPO rumah sakit }\end{array}$ & 1 & 33,3 & 2 & 66,7 & Baik \\
\hline 4 & $\begin{array}{l}\text { Penetapan SPO tentang pengembalian berkas } \\
\text { rekam medis rawat inap adalah } 2 \times 24 \text { jam }\end{array}$ & 2 & 66,7 & 1 & 33,3 & Kurang \\
\hline 5 & $\begin{array}{l}\text { Ketidaktepatan pengembalian berkas rekam } \\
\text { medis rawat inap dapat mengganggu pelayanan } \\
\text { rumah sakit }\end{array}$ & 2 & 66,7 & 1 & 33,3 & Kurang \\
\hline 6 & $\begin{array}{l}\text { Pengembalian berkas rekam medis rawat inap } \\
\text { yang tidak tepat waktu dapat menghambat } \\
\text { proses verifikasi BPJS }\end{array}$ & 3 & 100 & 0 & 0 & Baik \\
\hline 7 & $\begin{array}{l}\text { Ketidaktepatan pengembalian berkas rekam } \\
\text { medis dapat menghambat dalam pembuatan } \\
\text { laporan rumah sakit }\end{array}$ & 2 & 66,7 & 1 & 33,3 & Baik \\
\hline 8 & $\begin{array}{l}\text { Pengembalian berkas rekam medis tidak boleh } \\
\text { lebih dari } 2 \times 24 \text { jam setelah pasien pulang atau } \\
\text { meninggal }\end{array}$ & 2 & 66,7 & 1 & 33,3 & Kurang \\
\hline 9 & $\begin{array}{l}\text { Pengembalian berkas rekam medis ke unit } \\
\text { rekam medis merupakan tanggung jawab } \\
\text { petugas rekam medis }\end{array}$ & 3 & 100 & 0 & 0 & Baik \\
\hline 10 & $\begin{array}{l}\text { Sarana dan prasarana sangat diperlukan untuk } \\
\text { membantu dalam pengembalian berkas rekam }\end{array}$ & 2 & 66,7 & 1 & 33,3 & Baik \\
\hline
\end{tabular}




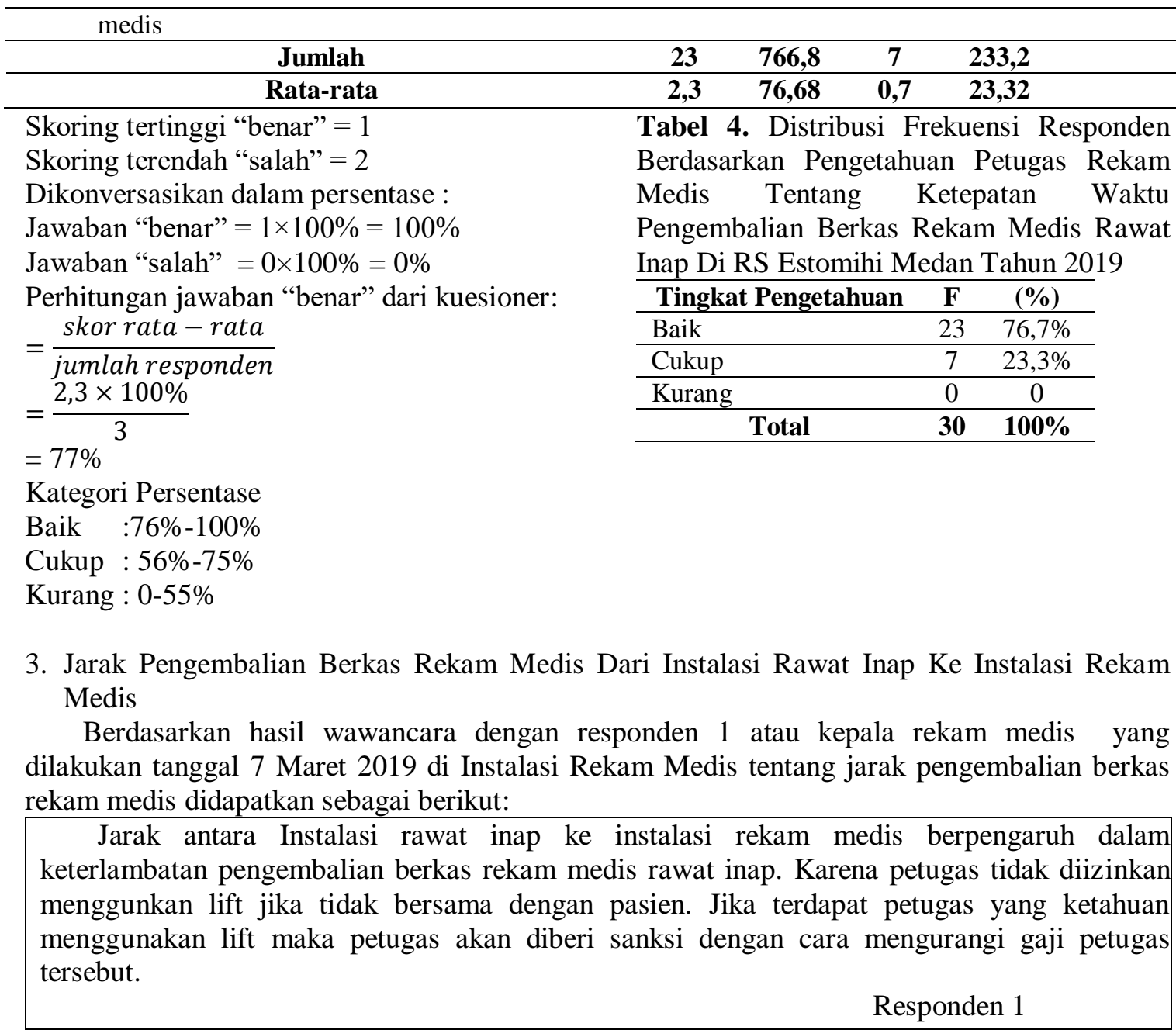

Perawat sering mengeluh dalam mengembalikan berkas rekam medis ke Instalasi rekam medis. Terkadang setelah berkas rekam medis sudah lengkap diisi dokter dan perawat, berkas rekam medis tidak langsung dikembalikan perawat ke Instalasi rekam medis dikarenakan beban kerja perawat yang tinggi diruangan dan imbul rasa lelah dan malas untuk mengembalikan berkas rekam medis ke Instalasi rekam medis.

Responden 2

Jarak tidak menjadi penyebab dalam pengembalian berkas rekam medis rawat inap, karena setelah berkas rekam medis sudah selesai dilengkapi maka berkas langsung di kembaliakn ke Instalasi rekam medis.

Resonden 3

\section{PEMBAHASAN}

\section{Pengembalian Berkas Rekam Medis}

Berdasarkan hasil jawaban responden saat melakukan wawancara diberikan penjelasan bahwa masih sering terjadinya keterlambatan pengembalian berkas rekam medis rawat inap hingga berhari-hari. Hal ini akan menghambat proses assembling dan dapat menjadi beban bagi petugas dalam pengolahan data, karena data yang diperoleh sudah mengalami keterlambatan berhari-hari maka pengolahannya juga akan mengalami keterlambatan. Dalam hal ini kegiatan pengembalian dari ruang rawat inap ke unit rekam medis belum memenuhi ketepatan dalam (PERMENKES No. 269, 2008) dan Standar Pelayanan Minimal tentang 
pengembalian berkas rekam medis di RS Estomihi Medan yang menetapkan pengembalian berkas rekam medis rawat inap $2 \times 24$ jam setelah pasien pulang dan meninggal.

Berdasarkan hasil penelitian menunjukkan bahwa pengembalian berkas rekam medis rawat inap di RS Estomihi Medan pada Bulan Februari-April 2019 dari total 87 berkas rekam medis rawat inap masih terjadi ketidaktepatan waktu pengembalian. Ketidaktepatan waktu pengembalian berkas rekam medis yang terjadi sebesar 63 berkas rekam medis dan yang tepat waktu sebesar 24 berkas rekam medis. Keterlambatan tertinggi terjadi pada bangsal Naomi yaitu 21 atau 77,78\% dan 6 atau $22,22 \%$ berkas rekam medis kembali tepat waktu. Keterlambatan terendah terjadi pada bangsal Maria yaitu 11 atau 55\% berkas rekam medis tidak tepat waktu dan 9 atau $45 \%$ berkas rekam medis kembali tepat waktu.

Faktor Penyebab Keterlambatan Waktu Pengembalian Berkas Rekam Medis Rawat Inap

1. Tingkat Kedisiplinan Dokter Dan Tanggung Jawab Dokter Dalam Pengisian Data Pada Berkas Rekam Medis Terutama Pada Bagian Resume Medis.

Berdasarkan hasil wawancara dengan responden 1 mengatakan bahwa dokter selalu menunda pengisian berkas rekam medis jika jumlah berkas hanya sedikit, jadi setelah berkas rekam medis bertumpuk di ruangan maka berkas baru akan dilengkapi oleh dokter. Berdasarkan hasil wawancara dengan responden 2 mengatakan bahwa keterlambatan pengembalian berkas rekam medis disebabkan oleh dokter. Dan sering terjadi setelah berkas sudah dilengkapi oleh dokter berkas tidak langsung dikembalikan oleh perawat dikarenakan beban kerja perawat di Instalasi rawat inap.

Keterangan yang sama juga didapatkan dari responden 3, mengatakan bahwa penyebab keterlambatan pengembalian berkas rekam medis disebabkan oleh dokter dan perawat yang tidak melengkapi berkas rekam medis rawat inap. Terkadang dokter akan membawa berkas rekam medis pulang kerumah untuk dilengkapi, dan setelah berkas rekam medis selesai dilengkapi maka berkas rekam medis akan dibawa kembali ke rumah sakit oleh dokter dan diserahkan kepada petugas assemblin.

Dari ketiga jawaban responden, peneliti mendapatkan keterangan bahwa penyebab keterlambatan pengembalian berkas rekam medis rawat inap disebabkan oleh dokter, perawat yang tidak disiplin dan kurang teliti dalam pengisian berkas rekam medis sehingga berkas rekam medis menjadi terlambat dan harus menunggu untuk dilengkapi terlebih dahulu. Menurut kebijakan Standar Prosedur Operasional yang ditetapkan di rumah sakit Estomihi bahwa berkas rekam medis rawat inap dikembalikan oleh perawat dari setiap ruang rawat inap ke bagian rekam medik setelah pasien pulang. Berkas rekam medis rawat inap harus kembali ke bagian rekam medik paling lambat $2 \times 24$ jam stelah pasien keluar rumah sakit, dan setiap berkas rekam medis yang kembali harus diperiksa kelengkapannya. (Menurut Ery Rustiyanto, 2019) mengenai tanggung jawab dokter yang merawat yaitu tanggung jawab utama akan kelengkapan rekam medis terletak pada dokter yang merawat. Dokter mengemban tanggung jawab terakhir akan kelengkapan dan kebenaran isi rekam medis.

2. Petugas Pengembalian Berkas Rekam Medis Yang Pengetahuannya Sesuai Dengan Bidang Keilmuan Nya

Hasil wawancara dengan responden pertama mengenai petugas pengembalian berkas rekam medis, Responden 1 mengtakan bahwa di rumah sakit Estomihi yang bertugas dalam pengembalian berkas rekam medis rawat inap ialah perawat ruangan di masing-masing Instalas rawat inap. Hasil wawancara dengan responden 2 mengatakan bahwa yang biasa bertugas dalam pengembalian berkas rekam medis rawat inap dilakukan oleh perawat ruangan, petugas rekam medis juga mengatakan bahwa belum ada petugas khusus dalam pengembalian berkas rekam medis rawat inap. Dan jika berkas rekam medis belum dikembalikan ke Instalasi rekam medis maka 
petugas rekam medis akan menelfon perawat Instalasi rekam medis untuk mengingatkan perawat agar mengembalikan berkas rekam medis ke Instalasi rekam medis.

Hasil wawancara dengan responden 3 mengatakan bahwa di Rumah Sakit Estomihi masih kekurangan SDM dalam pengembalian berkas rekam medis rawat inap, karena yang seharusnya bertugas dalam pengembalian berkas rekam medis rawat inap ialah petugas rekam medis yang pengetahuaannya sesuai dengan bidang keilmuannya. Berdasarkan wawancara yang dilakukan dengan 3 responden dikatakan bahwa belum terdapat petugas khusus pengembalian berkas rekam medis dan masih kurangnya SDM. Hal tersebut mengakibatkan adanya keterlambatan waktu pengembalian berkas rekam medis rawat inap di RS Estomihi medan yang terjadi hingga berhari-hari dan menumpuk di setiap ruangan. Sehingga sangat membantu jika dilakukan penambahan SDM dalam pengembalian berkas rekam medis rawat inap agar proses pengembalian lebih cepat dan mengurangi ketidaktepatan waktu pengembalian berkas rekam medis rawat inap. Dan dari hasil kuisioner diketahui bahwa dari 3 petugas rekam medis memiliki tingkat pengetahuan baik dengan persentase sebesar $76,7 \%$ tentang ketetapan batas waktu pengembalian berkas rekam medis dan ketentuan kelengkapan isi rekam medis tetapi petugas belum menjalankan peraturan sesuai dengan Standar Prosedur Operasional.

Menurut kebijakan Standar Prosedur Operasional yang ditetapkan di rumah sakit Estomihi bahwa berkas rekam medis rawat inap dikembalikan oleh perawat dari setiap ruang rawat inap ke bagian rekam medis setelah pasien pulang. Menurut (Renantha, 2017) menjelaskan bahwa uraian tugas pengembalian berkas rekam medis rawat inap mengurangi ketidaktepatan waktu pengembalian berkas rekam medis rawat inap. Jika terdapat petugas rekam medis yang khusus untuk pengembalian berkas rekam medis rawat inap akan lebih cepat dan membantu dalam proses pengembaliannya.
3. Jarak Pengembalian Berkas Rekam Medis Dari Instalasi Rawat Inap Ke Instalasi Rekam Medis

Hasil wawancara dengan responden 1 tentang jarak Instalasi rawat inap ke Instalasi rekam medis mengatakan bahwa jarak Instalasi rawat inap ke Instalasi rekam medis berpengaruh dalam keterlambatan waktu pengembalian berkas rekam medis rawat inap, dimana karena dalam pengembalian berkas rekam medis perawat tidak diizinkan menggunakan sarana seperti lift dalam pengembalian berkas rekam medis. Hasil wawancara dengan responden 2 mengatakan bahwa terkadang perawat sering mengeluh setiap mengembalikan berkas rekam medis ke Instalasi rekam medis. Dan terkadang setelah berkas rekam medis sudah lengkap diisi dokter dan perawat, berkas rekam medis tidak langsung dikembalikan perawat ke Instalasi rekam medis dikarenakan beban kerja perawat yang tinggi diruangan dan timbul rasa lelah dan malas untuk mengembalikan berkas rekam medis ke Instalasi rekam medis.

Hasil wawancara dengan responden 3 berbeda keterangannya dengan responden 1 dan 2 mengatakan bahwa tidak ada penyebab jarak antara Instalasi rawat inap ke Instalasi rekam medis karena setelah berkas rekam medis selesai dilengkapi berkas akan langsung di kembalikan ke Instalasi rekam medis. Berdasarkan wawancara yang dilakukan dengan 3 responden dikatakan bahwa 1 diantaranya menyatakan jarak antara instalasi rawat inap ke instalasi rekam medis tidak menjadi penyebab dalam keterlambatan pengembalian berkas rekam medis rawat inap karena jika berkas sudah selesai dilengkapi maka perawat akan langsung mengembalikan berkas rekam medis ke instalasi rekam medis. Berbeda pernyataan yang disampaikan oleh Responden 1 dan Responden 3, dua diantaranya menyatakan bahwa jarak antara instalasi rawat inap ke instalasi rekam medis menjadi salah satu penyebab dalam ketidaktepatan waktu pengembalian berkas rekam medis rawat inap.

Hal itu disebabkan karena instalasi rawat inap terletak di lantai 2 dan 3 sedangkan instalasi rekam medis terletak di 
lantai 6 dan dalam pengembalian berkas rekam medis ke Instalasi rekam medis ditempuh dengan jalan kaki menggunakan fasilitas tangga, karena petugas tidak diperkenankan menggunakan lift jika tidak bersama pasien dan berkas rekam medis dibawa dengan tangan. Hal ini menyebabkan perawat mengeluh saat mengembalikan berkas rekam medis ke Intalasi rekam medis. Maka dari itu karena jarak antara Instalasi rawat inap ke instalasi rekam medis jauh seharusnya pihak rumah sakit memperkenankan petugas menggunakan fasilitas rumah sakit seperti lift dan perlu ditambahkan sarana atau alat bantu seperti troli untuk mempermudah pengembalian berkas rekam medis ke Instalasi rekam medis.

Menurut (Renantha, 2017) bahwa pengembalian berkas rekam medis ke assembling yang ditempuh dengan jalan kaki dan berkas dibawa dengan tangan atau dengan troli, maka dari itu perlu ditambahkan sarana atau alat bantu dalam mempermudah pengembalian berkas rekam medis ke assembling, karena jarak antara Bangsal dengan Instalasi rekam medis jauh maka sarana seperti sepeda merupakan alat bantu yang yang digunakan oleh petugas.

\section{KESIMPULAN}

1. Dari hasil penelitian yang dilakukan keterlambatan waktu pengembalian berkas rekam medis rawat inap ke Instalasi rekam medis dari bulan Februari-April sebanyak 63 atau 72,41\% dari 87 berkas rekam medis rawat inap.

2. Dari hasil kuisioner diketahui bahwa rata-rata petugas rekam medis memiliki tingkat pengetahuan baik dengan persentase sebesar $76,7 \%$ tentang ketetapan batas waktu pengembalian berkas rekam medis dan ketentuan kelengkapan isi rekam medis tetapi petugas belum menjalankan peraturan sesuai dengan Standar Prosedur Operasional.

\section{SARAN}

1. Bagi Unit Rekam Medis

Sebaiknya dilakukan penambahan sumber daya manusia yang bertugas khusus dalam pengambilan dan pengembalian berkas rekam medis dari Instalasi rawat inap ke Instalasi rekam medis

2. Bagi Rumah Sakit

Sebaiknya pihak rumah sakit melakukan sosialisasi serta mengingatkan kembali dokter dan profesi medis yang lain ketika rapat tentang ketepatan pengembalian berkas rekam medis agar lebih meningkatkan kedispinannya dalam mengisi kelengkapan berkas rekam medis sesuai dengan kebijakan Standar Prosedur Operasional sehingga pengembalian berkas rekam medis tidak mengalami keterlambatan. Dan sebaiknya dilakukan peningkatan sarana pengembalian berkas rekam medis rawat inap seperti troli dan pemberian izin menggunakan lift.

\section{DAFTAR PUSTAKA}

Depkes RI. (2009). Undang-Undang Republik Indonesia Nomor 44 Tahun 2009 Tentang Rumah Sakit. Jakarta: Menteri Kesehatan Republik Indonesia.

Fatimah, Dkk. (2009). Langkah Mudah Membuat Usulan Proposal Kti Dan Laporan Hasil Kti. Jakarta: Trans Info Media.

Hasanah, Uswatun. (2014). Pengaruh Kelengkapan Resume Medis Terhadap Ketepatan Pengembalian Berkas Rekam Medis Rawat Inap Assembling Di RSUD.

Indradi, S, Rono. (2013). Materi Pokok Rekam Medis. Tangerang Selatan: Universitas Terbuka.

Jefriany, Renantha Silvi. (2017). Karya Tulis Ilmiah Ketepatan Pengembalian Berkas Rekam Medis Rawat Inap Di RS PAU Dr. Suhardi Hardjolukito Yogyakarta. Yogyakarta: Stikes Jenderal Achmad Yani.

Menteri Kesehatan RI. (2008). Peraturan Menteri Kesehatan Republik Indonesia 
Nomor 269/MENKES/PER/III/2008

Tentang Rekam Medis. Jakarta:

Departemen Kesehatan Republik Indonesia.

Notoatmodjo, Soekidjo. (2012). Metodologi Penelitian Kesehatan. Jakarta: Rineka Cipta.

Peraturan Menteri Kesehatan RI. (2013).

Tentang Pelayanan Kesehatan Pada Jaminan Kesehatan Nasional. Jakarta: Depkes RI.

Purba, Erlindai. (2016). Analisis FaktorFaktor Penyebab Keterlambatan Pemulangan Berkas Rekam Medis Dari
Instalasi Rawat Inap Ke Unit Instalasi Rekam Medis Di Rumah Sakit Vina Estetica Medan Periode Mei-Juli Tahun 2016. Jurnal Perekam Dan Informasi Kesehatan. Vo.1, No. 2, September 2016: 111.

Rustiyanto, E. (2009). Etika Profesi Perekam Medis Dan Informasi Kesehatan. Yogyakarta: Graha Ilmu.

Saryono, dkk. (2013). Metodologi Penelitian Kualitatif Dan Kuantitatif Dalam Bidang Kesehatan. Yogyakarta: Nuha Medika. 